\title{
Pathophysiology of Migraine
}

\section{Migren Patofizyolojisi}

\author{
H. Evren BORAN, Hayrunnisa BOLAY \\ Gazi University, Medical Faculty, Department of neurology, Ankara, Turkey
}

\section{ABSTRACT}

Migraine is a serious health problem which impair quality of life. It is the second most common primary headache that affects approximately more than $\% 10$ people in general population. Migraine pathophysiology is still unclear. Increasing results of studies suggest to migraine pathophysiology is related with primary neuronal mechanisms. Migraine pain starts in which region of brain and what brain regions are activated in different stages is unenlightened. There is evidences that growing number of studies which using new imaging techniques as positron emission tomography (PET) and functional magnetic resonans imaging (fMRI) show that migraine and cluster headaches are related with neuronal structures and vasodilatation. There are four phases to a migraine. The prodrome phase, aura, the attack, and the postdrome phase. Some datas obtained from last ten years indicate that cortical excitability has increased in interictal phase too. For many years, studies in rodents show trgimenial nerve is activated and it leads to vasodilatation and neurogenic inflammation in the headache phase. Although the majority of patients encountered in clinical practice are migraine without aura or chronic migraine, experimental studies of the migraine pathophysiology are focusing on the aura model which is used cortical spreading depression. (Archives of Neuropsychiatry 2013; 50 Supplement 1: S1-S7)

Key words: Migraine, aura, cortical spreading depression, cortical excitability, trigeminovascular system

Conflict of interest: The authors reported no conflict of interest related to this article.

\section{Introduction}

Migraine is a severe health problem which is the second most common one among the primary headaches, which affects more than $10 \%$ of the general population and which affects the quality of life negatively (1). The prevalence of life-time migraine in Turkey has been found to be $16 \%$ (10.9\% in men and $21.8 \%$ in women) (2). The pathogenesis of migraine is stil unclear. The increasing results of studies suggest that the pathophysiology of migrain is related with primary neuronal mechanisms.

It was impossible to demostrate that primary headaches were not structural before new imaging methods including positron emission tomography (PET) and functional magnetic resonance

\section{ÖZET}

Migren, yaşam kalitesini bozan ciddi bir sağlık problemidir. Primer baş ağrılarında ikinci sıklıkta görülen migren, genel populasyonun yaklaşı \%10'undan fazlasını etkilemektedir. Migren patogenezi hala belirsizliğini korumaktadır. Giderek artan çalışma sonuçları migren patofizyolojisinin primer nöronal mekanizmalarla ilgili olduğunu düşündürmektedir. Migren ağrısının hangi beyin bölgesinden başladığı ve farklı migren evrelerinde hangi beyin bölgelerinin aktif olduğu aydınlatılamamıs bir konudur. Pozitron emisyon tomografi (PET) ve fonksiyonel manyetik rezonans (fMR) gibi yeni görüntüleme yöntemleriyle birlikte migren ve küme baş ağrılarının nöronal yapılarla ilgili olduğunu ve damar dilatasyonu ile ilgisini gösteren artan sayıda kanıtlar bulunmaktadır. Migren kliniği prodrom, aura, baş ağrısı ve postrom dediğimiz 4 ayrı evreden oluşmaktadır. Son on yılda elde edilen bazı veriler interiktal dönemde de beyin aktivitesinin uyarılabilirlik yönünde arttığına işaret etmektedir. Uzun yıllardır kemirgenlerde yapılan çalışmalar ise baş ağrısı evresinde trigeminal sinirin aktive olduğunu ve buna ikincil damarlarda genişleme ve nörojenik inflamasyon olduğunu göstermiştir. Klinik pratikte karşılaşılan hastaların büyük çoğunluğu aurasız migren, kronik migren hastaları olmakla beraber patofizyolojiye ait deneysel calısmalar aura modeli olarak kullanılan kortikal yayılan depresyon üzerine odaklanarak gitmektedir. (Nöropsikiyatri Arşivi 2013; 50 Özel Sayı 1: S1-S7)

Anahtar kelimeler: Migren, aura, kortikal yayılan depresyon, kortikal eksitabilite, trigeminovasküler sistem

Çıkar çatışması: Yazarlar bu makale ile ilgili olarak herhangi bir çıkar çatışması bildirmemişlerdir.

imaging (fMRI). Wtih these methods, increased evidence has been found indicating that migraine amd cluster headaches are related with neuronal structures and vascular dilatation.

It is not clear how and from which area of the brain the migraine pain starts and which brain areas are active in the different stages of migraine. The clinical picture of migraine is composed of 4 different stages including the prodromal stage, aura stage, headache stage and postdromal stage and some evidence obtained in the last ten years indicate that the brain activity is increased in direction of exitability also in the interictal period. In addition, the effect of the aura stage to initiate pain is controversial and detailed studies show that most patients have headache during aura. 
In the profromal stage, symptoms related with the brain stem nuclei and limbic system occur. It is accepted that the aura stage during which visual, sensory and motor transient neurological deficits are observed frequently arises from the cortex. Studies which have been conducted in rodents for long years have shown that the trigemila nerve is activated in the headache period and vasodilatation and neurogenic inflammation secondary to this activation occur. In human studies, these hypotheses proposed could not be proven. Aura on which studies have been intensified and controversial issues persist, cortical spreading depression and brain stem structures will be emphasized In the pathophysiology. Although the majority of patients encountered in clinical practice have migraine without aura and chronic migraine, experimental studies related with pathophysiology are emphasized on the cortical spreading depression which is used as the aura model.

\section{Migraine Aura}

Aura is a transient neurological deficit which is observed before headache in $20 \%$ of the patients with migraine. Although visual aura (including visual hallucination) is observed most commonly, sensor yor motor auras may also be observed (3). The symptoms of visual aura spreas along the cerebral cortex and typically occurs with positive phenomenon (syntillations) following negative symptoms (scotoma).

Harold G. Wolff who is the leader of vascular theory in migraine stated that aura symptoms were related with cerebral vasoconstriction and headache was related with vasodilatation (4).

Lashley showed that the origin of visual aura was the opposite occipital cortex in 1941 and calculated that the symptoms spread at a speed of 3-5 mm/min (5). This phenomenon is related with Leao's depression waves in the cerebral cortex $(6,7)$. He defended that it was related with Leao's spreading cortical depression phenomenon and brought out the neuronal theory in migraine.

fMRI studies have shown that the visual aura symptoms in migraine are related with blood flow change in the occipital cortex $(8,9)$. With use of $\mathrm{fMRI}$ technique occipital cortex activation was observed by visual stimulation. In the study performed by Cao et al. in 1999 , migraine was triggered visually in $50 \%$ of the subjects and the events in the early period of the attack were evaluated primarily (10). Headache did not develop in any of the 6 controls and normal BOLD signals were obtained in visual activation. Headache triggered with visual stimulus was observed in 6 patients with migraine with aura and in 2 patients with migraine without aura and visual changes accompanied in 2 . Before headache supression in the brain activity which progressed continuously was observed in the occipital cortex at an interval of $3-6 \mathrm{~mm} / \mathrm{min}$. Increased intensity which indicated tissue hyperoxigenation and vasodilatation accompanied this neuronal supression. In the study performed by Hadjikhani et al. (9) in 2001, it was shown that the same changes occured in spontaneous migraine with aura on fMRI as observed in the study of Cao et al. (10). In the fMRI study performed by Hadjikhani et al., it was shown that hyperemia occured following focal oligemia and spread anteriorly independent of the vascular areas. Disruption of the blood flow and its spreading anteriorly correspond to the aura symptoms and peripheral movement in the retinotopic organization in the occipital cortex (9). This increased intensity which indicates tissue hyperoxigenation was also demonstrated in experimental cortical spreading depression (11).
Wood et al. showed that the same spreading events were present on PET in a migraine attack without aura, though this was a single case (12). These spreading events accompanied headache which was triggered visually independent of presence or absence of visual change. The cortical spreading dperession mechanism in migraine was confirmed with these studies and these studies do not clearly support ischemia in migraine aura.

In another perfusion-weighted imaging (PWI) study, 128 attacks were visualized in 9 patients with migraine with aura (13). In patients with migraine with aura with visual defect, it was shown that the blood flow decreased relatively in the contralateral occipital cortex, but no change occured in the other brain areas except fort he occipital cortex. No change in the blood flow was observed in patients with migraine without aura.

\section{Cortical Spreading Depression}

Cortical spreading depression (CSD) is thought to be related with massive depolarization of neuronal membranes in the gray matter and extraordinary exitability in ion change status (14). It was shown that spreading depression waves to which neuronal, glial and vascular cells participated affected the cerebral cotex visibly $(15,16)$. Depolarization which occurs in the brain parenchyma causes to release of vasoactive and nociceptive ions including potassium, hydrogen, nitric oxixde, glutamate and arachidonic acid metabolites $(17,18)$.

Neuronal firing induced by cortical spreading depression reaches its peak in 20 minutes followinf cortical spreading depression. In addition, it was shown that CSD caused to a decrease in activation of matrix metalloproteinase 9 in the piaglial barrier and cerebral cortex and a decrease in lamin and other markers in the blood-brain barrier and compartmental barrier (19). It was also shown that nociceptive molecules including HMBP1 released during CSD in rodents mediated activation of the trigeminal nerve (19). Conclusively, studies performed in rodents showed that CSD waves triggered trigeminal vascular fibers and caused to lateralized pain $(15,20)$. Additionally, CSD activates the trigeminovascular system by causing to various cellular and vascular changes in the meningeal membrane (pia mater, arachnoid mater and dura mater) (15).

There are fMRI studies showing that CSD contributes to complex vascular phenomena in patients with migraine. It was found that spreading depression was related with mutliphasic vascular response in mice. Dilatation in cortical superficial vessels may spread along the vessels due to intrinsic vascular mechanism (20). Afterwards, following regional vasodilatation the diameter returns to the normal value and vasoconstriction occurs $(20,21)$. As a response to CSD the presence of vasoconstriction in the superficial components may vary according to species and methodologies. In humans, hypoperfusion with vasoconstriction was shown by fMRI studies in patients with migraine with aura an deven without aura $(10,22,23)$. In in vivo imaging studies, it was shown that astrocytes with CSD and calcium waves initiated vasoconstriction in rodents (24).

\section{Migraine and Cortical Exitability}

There are clinical electrophysiological studies showing cortical exitability changes in migraine. In many studies, an increase in the amplitude of cortical evoked potentials and a decrease in habituation was shown in the interictal period in patients with migraine compared to controls and these differences disappeared in the ictal period (25). In other studies, a decrease in the threshold 
of phosphene formed with transcranial magnetic stimulation (TMS) was shown in patients with migraine $(26,27,28)$. TMS application to the occipital cortex in order to evaluate the underlying exitability in spontaneous migraine aura or migriane aura triggered visually may be more relevant in terms of migraine (29). In a study which evaluated the formation of phsphenes by applying TMS to the occipital cortex, it was found that the threshold of phosphene formation was low in patients with migraine with aura and was related with hyperexitability in the occipital cortex (30). In patients with migraine, a decrease in visual accuracy supression induced by TMS was shown (31). While the sensorial cortex gave excessive reaction to repetetive stimuli in patients with migraine, normal habituation was observed in healthy controls in contrast. In addition, distupted cortical inhibitor responses and marked intracortical fascilitation were reported şn patients with migraine $(32,33)$.

There are many srudies investigating the motor cortex by using TMS in patients with migraine. In three studies, the motor cortex was examined and increased exitability was found in patients with migraine in 2 studies. It was thought that these neurophysiological findings were involved in the mechanism of migraine $(34,35)$. In the study in which patients with migraine with and without aura were compared with controls, it was shown that the motor threshold was increased in migraine (35). These findings indicate increased cortical exitability or decreased inhibition in patients with migraine.

In addition, there are also studies suggesting that the cortical exitability is decreased in migraine in contrast to the known fact (36). The difference here might have arised from the difference in the methodologies of the studies. Another explanation may be the difference in exitability in time in patients with migraine. With this view, differences in the threshold of formation of phosphene were observed with repetetive TMS stimuli in patients with migraine compared to controls (37). This suggests disregulation of cortical exitability in patients with migraine independent of presence of increased or decreased cortical exitability $(36,38)$. Abnormal change in cortical exitability may play a role in explaining different symptoms of patients with migraine.

For cortical spreading depression to initiate a change in the exitability in the cerebral cortex must occur. Glial cells play a key role in change of cortical exitability in migraine. There is evidence indicating that mutation of $\mathrm{Na}+/ \mathrm{K}+$ ATPase primaily expressed in astrocytes is responsible in familial hemiplegic migraine type 2 (39,

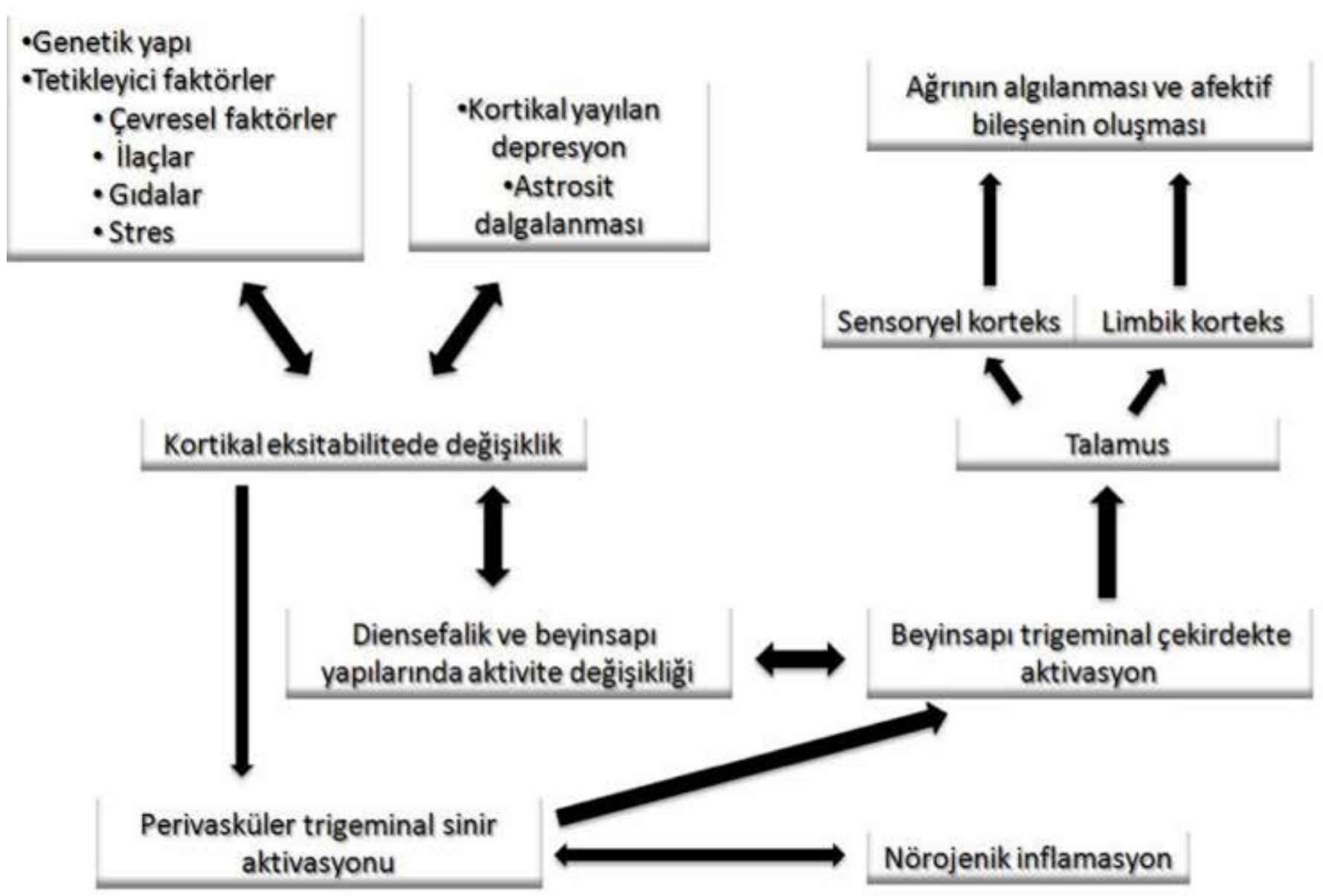

Figure 1. Brief diagram of the pathophysiology of migraine 
40). In vitro studies suggest that this mutation increases exitability by increasing extracellular potassium with decreased enzyme functions $(40,41)$. This view was supported with studies conducted with pharamcologicalagents initiating cortical spreading depression including potassium, glutamate, NMDA and NA+/K+ ATPase inhibitor ouabain $(42,43)$.

\section{Migraine and the Brain stem}

There are strong findings indicating that the brain stem has an important role in the pathophysiology of migraine. Symptoms including nausea, vertigo and autonomic symptoms are thought to arise from the brain stem.

PET screening showed an increase in cerebral metabolism in the brain stem compared to the other areas in 10 patients with migraine (31). In addition, it was shown that the cerebral metabolism was decreased in the parietal area including the medial frontal and somatosensorial cortex. This suggests that the normal inhibitory effect of higher cortical centers is decreased and the activity of the brain stem is increased in pain pathways in patients with chronic migraine. Because of anatomical localization defect of PET it is thought that activation occurs in the dorsal raphe nucleus, periaquaductal grey matter (PAG) and locus coeruleus (44). There is a single case report reporting activation of red nucleus and substantia nigra in spontaneous migraine attack (45). The same investigators found that the red nucleus and substantia nigra were also activated in migraine triggered visually (46). It is known that the red nucleus and substantia nigra have functional role in motor control. The red nucleus is also related with pain and nociception (47). In many animal studies, the red nucleus was shown to be involved in sensory and noxious stimulation. Ipsilateral red nucleus activation was shown in pain induced by capsaicin. It is stil not known if the red nucleus is involved in pain pathways or in motor response to pain.

fMRI studies show that the brain stem and especially the dorsolateral pons is activated during migraine attacks $(48,49,50)$. It is thought that brain stem dysfunction due to activation of the dorsal pons and PAG during migraine attacks plays a role as a generator in migraine pain $(51,52)$. PAG and other neuromodulator structures including rostral ventromedial medulla, locus coeruleus, raphe nucleus are primarily involved in modulation of nociception (53). Imaging studies have shown that PAG is a prat of the descendent pathway in high cortical control in pain modulation (54). PAG has a great role im nociceptive pathways in connections coming from the thalamus, hypothalamus and autonomic nervous system. PET and fMRI studies have shown that the metabolism and function of the brain stem is changed in patients with chronic migraine (31, 55). In an interictal imaging study, it was shown that dysfunction of PAG increased as the chronicicity of migraine increased (56). In a study performed with PET in migraine, it was found that PAG was hyperacitve (48). The ventrolateral lower part of PAG has an important role in modulation of trigeminal nociception (57). It has been shown that hyperactivity of the nociceptive system has a genetic predisposition (58). It was found that o-agatoxin-IVA which is a $P / Q$ channel blocker administerred into the ventrolateral PAG of rats by microinjection fascilitated neuronal activity in the trigeminal nociceptive pathway (57). This study showed the effect of both $P / 0$ tyep calcium channels and PAG in trigeminal proprioception. In another study, electrical stimulation of PAG was shown to cause to headache (59).
In addition, there are many publications suggesting that structural lesions in the brain stem cause to headache $(60,61,62)$.

In fMRI studies, many brain areas were found to be related with nociception during migraine attacks $(44,63,64)$, but it is not clearly known where the first activation is initiated in the nociceptive pathways.

\section{Trigeminovascular System}

It is accepted that the trigeminovascular system plays an important role in headache. This fidning is based on the fact that the vessels innervated by the trigeminal way cause to headache in patients with an open consciousness, while stimulation of the brain parenchyma does not lead to any discomfort $(65,66)$.

The trigeminal nerve and ophtalmic nerve play an important role in transportation of pain impulses from the intracranial structures $(67,68)$. According to the data obtained from rodents, neurogenic inflammation in the dura mater, plasma protein extravasation, increased blood flow and vasodilatation play an important role in the headache phase (69). In the characteristic headache phase, CSD was found to have an important role in trigeminovascular activation and neurogenic edema (15). CSD cause to an increase in the blood flow in the arteries supplying the dura mater by way of the trigeminal nerve. In anesthetic rodents, the blood flow in the middle meningela artery reaches a peak in 20 minutes following cortical spreading depression and the blood flow returns to normal in 50 minutes. In addition, cortical spreading depression induces trigeminal nerve mediated plasma protein extravasation in the ipsilateral dura mater in rodents. It was shown to induce secondary neurons in peripheral changes by demonstrating $\mathrm{c}$-fos staining in the ipsilateral superficial nociceptive lamina $(15,70)$.

One of important mediators in plasma protein extravasation is nitric oxide (NO). NO is released from the vascular cells in response to constriction. Migraine can be triggered by nitroglycerine infusion. With this induction, headache starts 4-6 hours later (71). It is thought that the underlying mechanism of this includes delayed inflammatory response in the dura mater, increase in iNOS expression and upregulation of proinflammatory cytokines including IL-1 and IL-6 (72). In another theory, fluctuation in NO may lead to migraine pain by activating the trigeminal vascular system independent of plasma protein extravasation without the contribution of cortical structures.

Vasoconstiction related with cortical spreading depression and/or astrocyte calcium fluctuations may lead to a change in the metabolic activity and blood flow. Decreased parenchymal blood flow causes release of cellular metabolites by affecting the neuronal glial activity and triggers the nociceptive response by decreasing extracellular $\mathrm{pH}$. For example, transient receptors in nociceptive trigeminal neurons or change in ion channels may be activated in these conditions (73).

Trigeminal neurons innervate the meninges in many ways including visceral sensory neurons (74). The relation between triggering of sensory neurons by specific stimuli and occurence of migraine pain is not clear. Additional factors may also be responsible; mechanical compression, ion changes in the extracellular space (increased potasssium, increased osmolarity, decreased $\mathrm{pH}$ ), neuropeptides (bradykinin, substans $P$, endothelin, calcitonin generelated peptide (CGRP), neurotransmitters (glutamate, serotonin, histamin, adenosine triphosphate (ATP), adenosine) eicosanoids 
and NO. The subunits of the trigeminal neurons may give specific responses with different stimuli at different thresholds (75).

In addition, recent studies have shown that astrocytes affect both neuronal and vascular activity by playing a role in intracellular signalling. Astrocytes affect the neuronal activity by expressing many neurotransmitter receptors (76). On the other hand, glutamate which modulates neuronal function provides transmitter release including ATP (77). Astrocytes wrap the vessels with their feet close to the vascular cells. Astrocyte signal affects the vascular tonus directly and causes to vasoconstriction or vasodilatation depending on release of eicosanoid, potassium and ATP $(78,79,80)$.

Conclusively, CSD and intrinsic brain prenchymal events cause to lateralized pain by triggering the trigeminovascular fibers.

The role of the activation of the trigeminovascular system supports the change due to perivascular trigeminal nociceptive inhibition with the effect of triptan and recently CGRP antagonist effect. With detection of the binding sites of the primary afferents in the human brain stem to the $5 \mathrm{HT} 1 \mathrm{~B} / \mathrm{D}$ agonists in the central system, the importance of the tirgeminovascular system has increased further $(81,82)$. Other migraine therapies including ergotamine have been proposed to affect primarly the peripheral trigeminal vascular complex as well as central mechanisms (83). CGRP is accepted to be an important mediator in migraine and is released to protect the vascular tonus as a response to vasoconstiction in the perivascular neurons. It was shown that neurons containing CGRP were present in the central and peripheral nervous system (including trigeminal nucleus caudalis in the brain stem) and contituted an alternative source for release of CGRP during migraine attacks (84, $85,86,87)$. The role of the trigeminovascular system is supported by observation of an increase in CGRP which is involved in cerebral vasoregulation in the jugular vein during migraine attakcs. (88)

Interestingly, trigeminal risotomy was not efficient in preventing migraine of cluster headache, although the sensory function of the trigeminal nerve was disrupted (89). With this result, headache in the absence of peripheral trigeminal input in the ipsilateral side suggests the probable response of the nociceptive pathways.

\section{Conclusion}

Migraine attack occurs with neuronal and vascular changes in which CSD, cortical exitability and the trigeminovascular system are involved. The pathophysiology of migraine has not been elucidated fully yet. Especially migraine without aura, chronicity, the relation of C-fibers mediated pain with the brain cortex, subcortical structures and brain stem, neuropeptide contents and general trigerring responses including NO need to be examined in detail and experimental studies should be performed in a translation fashion.

\section{References}

1. Rasmussen BK, Jensen R, Schroll M, Olesen J. Epidemiology of headache in a general population-a prevalence study. J Cli Epidemiology 1991; 44:1147-1157.

2. Zarifoglu M, Siva A, Hayran 0 . the Turkish headache epidemiology study group. An epidemiological study of headache in Turkey: a nationwide survey. Neurology 1998; 50(suppl 4):80-85.
3. Cutrer FM, Huerter K. Migraine aura. Neurologist 2007; 13:118-125.

4. Wolff HG. Headache and other head pain. 2nd edn. Oxford University Press. New York; 1963.

5. Lashley KS. Patterns of cerebral integration indicated by the scotomas of migraine. Arch Neurol Psychiatry 1941; 46:331-339.

6. Leao AAP. Spreading depression of activity in cerebral cortex. $J$ Neurophysiol 1944; 7:359-390.

7. Milner PM. Note on a possible correspondence between the scotomas of migraine and spreading depression of Leao. Electroencephalogr Clin Neurophysiol 1958; 10:705.

8. Olesen J, Larsen B, Lauritzen M. Focal hyperemia followed by spreading oligemia and impaired activation of rCBF in classic migraine. Ann Neurol 1981; 9:344-352.

9. Hadjikhani N, Sanchez Del Rio M, Wu O, Schwartz D, Bakker D, Fischl B, Kwong KK, Cutrer FM, Rosen BR, Tootell RB, Sorensen AG, Moskowitz MA. Mechanisms of migraine aura revealed by functional MRI in human visual cortex. Proc Natl Acad Sci USA 2001; 98:4687-4692.

10. Cao Y, Welch KM, Aurora S, Vikingstad EM. Functional MRI-BOLD of visually triggered headache and visual change in migraine sufferers. Arch Neurol 1999; 56:548-554.

11. Gardner-Medwin AR, van Bruggen N, Williams SR, Ahier RG. Magnetic resonance imaging of propagating waves of spreading depression in the anaesthetised rat. J Cereb Blood Flow Metab 1994; 14:7-11.

12. Woods RP, lacoboni M, Mazziotta JC. Bilateral spreading cerebral hypoperfusion during spontaneous migraine headache. N Engl J Med 1994; 22:1689-1692.

13. Sanchez del Rio M, Bakker D, Wu O, Agosti R, Mitsikostas DD, Ostergaard L, Wells WA, Rosen BR, Sorensen G, Moskowitz MA, Cutrer FM.SourceDepartment of Neurology, Magnetic Resonance Center, Boston, MA, USA. sanchezm@helix.mgh.harvard.edu. Perfusion weighted imaging during migraine spontaneous visual aura and headache. Cephalalgia 1999; 19:701-707.

14. Smith JM, Bradley DP, James MF, Huang CL. Physiological studies of cortical spreading depression. Biol Rev 2006; 81:457-481.

15. Bolay H, Reuter U, Dunn AK, Huang Z, Boas DA, Moskowitz MA. Intrinsic brain activity triggers trigeminal meningeal afferents in a migraine model. Nat Med 2002; 8:136-142.

16. Bolay $\mathrm{H}$, Moskowitz MA. The emerging importance of cortical spreading depression in migraine headache. Rev Neurol (Paris) 2005; 161:655-657.

17. Kraig RP, Nicholson C. Extracellular ionic variations during spreading depression. Neuroscience 1978; 3:1045-1059.

18. Obrenovitch TP, Urenjak J, Wang M. Nitric oxide formation during cortical spreading depression is critical for rapid subsequent recovery of ionic homeostasis. J Cereb Blood Flow Metab 2002; 22:680-688.

19. Karatas H, Erdener SE, Gursoy-Ozdemir Y, Lule S, Eren-Koçak E, Sen ZD, Dalkara T. Spreading Depression Triggers Headache by Activating Neuronal Panx1 Channels. Science 2013; 339:1092-1095.

20. Zhang X, Levy D, Noseda R, Kainz V, Jakubowski M, Burstein R. Activation of Meningeal Nociceptors by Cortical Spreading Depression: Implications for Migraine with Aura. J. Neurosci 2010; 30:8807-8814.

21. Brennan KC, Beltrán-Parrazal L, López-Valdés HE, Theriot J, Toga AW, Charles AC. Distinct vascular conduction with cortical spreading depression. J Neurophysiol 2007; 97:4143-4151.

22. Woods RP, lacoboni M, Mazziotta JC. Bilateral spreading cerebral hypoperfusion during spontaneous migraine headache. N Engl J Med 1994; 331:1689-1692.

23. Géraud G, Denuelle M, Fabre N, Payoux P, Chollet F. [Positron emission tomographic studies of migraine.] Rev Neurol (Paris) 2005; 161:666-670.

24. Chuquet J, Hollender L, Nimchinsky EA Highresolution in vivo imaging of the neurovascular unit during spreading depression. J Neurosci 2007; 27:4036-4044.

25. Schoenen J. Neurophysiological features of the migrainous brain. Neurol Sci 2006; 27(Suppl 2):77-81.

26. Aurora SK, Cao Y, Bowyer SM, Welch KM. The occipital cortex is hyperexcitable in migraine: experimental evidence. Headache 1999; 39:469476.

27. Aurora SK, Welch KMA, Al-Sayed F. The threshold for phosphenes is lower in migraine. Cephalalgia 2003; 23:258-263. 
28. Gerwig M, Niehaus L, Kastrup 0, Stude P, Diener HC. Visual cortex excitability in migraine evaluated by single and paired magnetic stimuli. Headache: J Head Face Pain 2005; 45:1394-1399.

29. Teive HA, Kowacs PA, Maranhão Filho P, Piovesan EJ, Werneck LC. Lea o's cortical spreading depression:from experimental "artifact" to physiological principle. Neurology 2005; 65:1455-1459.

30. Aurora SK, Al-Sayed F, Welch KMA The threshold for magnetophoshenes is lower in migraine. Neurology 1999; 52:472.

31. Aurora SK, Barrodale PM, Tipton RL, Khodavirdi A. Brainstem dysfunction in chronic migraine as evidenced by neurophysiological and positron emission tomography studies. Headache 2007; 47:996-1003.

32. Chadaide Z, Arlt S, Antal A, Nitsche MA, Lang N, Paulus W. Transcrania direct current stimulation reveals inhibitory deficiency in migraine. Cephalalgia 2007; 27:833-839.

33. Cosentino G, Fierro B, Vigneri S, Talamanca S, Palermo A, Puma A, Brighina F. Impaired glutamatergic neurotransmission in migraine with aura? Evidence by an input-output curves transcranial magnetic stimulation study. Headache 2011; 51:726-733.

34. Bettucci D, Cantello R, Gianelli M, Naldi P, Mutani R. Menstrual migraine without aura: cortical excitability to magnetic stimulation. Headache 1992 32:345-347.

35. Maertens de Noordhout A, Pepin JL, Schoenen J, Delwaide PJ. Percutaneous magnetic stimulation of the motor cortex in migraine Electroencephalogr Clin Neurophysiol 1992; 85:110-115.

36. Ambrosini A, Shoenen J.Electrophysiological response patterns of primary sensory cortices in migraine. J Headache Pain 2006; 7:377-388.

37. Antal A, Arlt S, Nitsche MA, Chadaide Z, Paulus W. Higher variability of phosphene thresholds in migraineurs than in controls: a consecutive transcranial magnetic stimulation study. Cephalalgia 2006; 26:865-870.

38. Stankewitz A, May A. Cortical excitability and migraine. Cephalalgia 2007; 27:1454-1456.

39. De Fusco M, Marconi R, Silvestri L, Atorino L, Rampoldi L, Morgante L, Ballabio A, Aridon P, Casari G. Haploinsufficiency of ATP1A2 encoding the $\mathrm{Na}$ ş/K ş pump alpha2 subunit associated with familial hemiplegic migraine type 2. Nat Genet 2003; 33:192-196.

40. Vanmolkot KR, Kors EE, Turk U, Turkdogan D, Keyser A, Broos LA, Kia SK, van den Heuvel JJ, Black DF, Haan J, Frants RR, Barone V, Ferrar MD, Casari G, Koenderink JB, van den Maagdenberg AM. Two de novo mutations in the Na,K-ATPase gene ATP1A2 associated with pure familial hemiplegic migraine. Eur J. Human Genetics 2006; 14:555-560.

41. Segall L, Mezzetti A, Scanzano R, Gargus JJ, Purisima E, Blostein R. Alterations in the alpha2 isoform of $\mathrm{Na}, \mathrm{K}$-ATPase associated with familial hemiplegic migraine type 2. Proc Natl Acad Sci U S A 2005; 102:1110611111.

42. Smith JM, Bradley DP, James MF, Huang CL. Physiological studies of cortical spreading depression. Biol Rev Camb Philos Soc 2006; 81:457-481.

43. Akcali D, Sayin A, Sara Y, Bolay H. Does single cortical spreading depression elicit pain behaviour in freely moving rats? Cephalalgia 2010 30:1195-1206

44. Weiller C, May A, Limmroth V, Jüptner M, Kaube H, Schayck RV, Coenen $\mathrm{HH}$, Diener HC. Brainstem activation in spontaneous human migraine attacks. Nat Med 1995; 1:658-660.

45. Welch KM, Cao Y, Aurora S, Wiggins G, Vikingstad EM. MRI of the occipital cortex, red nucleus, and substantia nigra during visual aura of migraine. Neurology 1998; 51:1465-1469.

46. Cao Y, Aurora SK, Vikingstad EM, Patel SC, Welch KMA. Functional MRI of the red nucleus and occipital cortex during visual stimulation of subjects with migraine. Cepahalalgia 1999; 19:462.

47. Iadarola MJ, Berman KF, Zeffiro TA, Byas-Smith MG, Gracely RH, Max MB, Bennett GJ. Neural activation during acute capsaicin-evoked pain and allodynia assessed with PET. Brain 1998; 121:931-947.

48. Bahra A, Matharu MS, Buchel C, Frackowiak RS, Goadsby PJ. Brainstem activation specific to migraine headache. Lancet. 2001; 357:1016-1017.

49. Afridi SK, Matharu MS, Lee L, Kaube H, Friston KJ, Frackowiak RS, Goadsby PJ. A PET study exploring the laterality of brainstem activation in migraine using glyceryl trinitrate. Brain 2005; 128:932-939.

50. Denuelle M, Fabre N, Payoux P, Chollet F, Geraud G. Hypothalamic activation in spontaneous migraine attacks. Headache 2007; 47:1418-1426.

51. Akerman S, Holland PR, Goadsby PJ. Diencephalic and brainstem mechanisms in migraine. Nat Rev Neurosci. 2011;12(10):570-84.
52. Weiller C, Mayıs A, Limmroth V, Jüptner M, Kaube H, Schayck RV, Coenen $\mathrm{HH}$, Diener HC. Brain stem activation in spontaneous human migraine attacks. Nat Med 1995; 1:658-660.

53. Jones SL. Descending noradrenergic influences on pain. Progress Brain Res 1991; 88:381-94.

54. Tracey I, Ploghaus A, Gati JS, Clare S, Smith S, Menon RS, Matthews PM. Imaging attentional modulation of pain in the periaqueductal gray in humans. J Neurosci 2002; 22:2748-2752.

55. Aurora SK, Barrodale PM, Tipton RL, Khodavirdi A. Brainstem dysfunction in chronic migraine as evidenced by neurophysiological and positron emission tomography studies. Headache. 2007:47:996-1003.

56. Welch KM, Nagehan V, Aurora SK, Gelman N. Periaqueductal gray matter dysfunction in migraine: cause or the burden of illness. Headache 2001; 41:629-637.

57. Knight YE, Goadsby PJ. The periaqueductal grey matter modulates trigeminovascular input: a role in migraine? Neuroscience 2001; 106:793800.

58. Knight YE, Bartsch T, Kaube H, Goadsby PJ. P/Q-type calcium- channel blockade in the periaqueductal gray facilitates trigeminal nociception: a functional genetic link for migraine. J Neurosci 2002; 22:RC213.

59. Raskin NH, Hosobuchi Y, Lamb S. Headache may arise from perturbation of brain. Headache 1987; 27:416-420.

60. Haas DC, Kent PF, Friedman DI. Headache caused by a single lesion of multiple sclerosis in the periaqueductal gray area. Headache 1993; 33:452455.

61. Goadsby PJ. Neurovascular headache and a midbrain vascular malformation: evidence for a role of the brainstem in chronic migraine. Cephalalgia 2002; 22:107-111.

62. Fragoso YD, Brooks JB. Two cases of lesions in brainstem in multiple sclerosis and refractory migraine. Headache 2007; 47:852-854.

63. Cao Y, Welch KM, Aurora S, Vikingstad EM. Functional MRIBOLD of visually triggered headache in patients with migraine. Arch Neurol 1999; 56:548-554.

64. Denuelle M, Fabre N, Payoux $P$, Chollet F, Geraud G. Hypothalamic activation in spontaneous migraine attacks. Headache 2007; 47:1418-1426.

65. Penfield W. A contribution to the mechanism of intracranial pain. Assoc Res Nerv Ment Dis 1935; 15:399-416.

66. Ray BS, Wolff HG. Experimental studies in headache: Pain-sensitive structures of the head and their structural significance. Arch Surg 1940; 41:813-856.

67. M ayberg MR, Zervas NT, Moskowitz MA. Trigeminal projections to supratentorial pial and dural blood vessels in cats demonstrated by horseradish peroxidase histochemistry. J Comp Neurology 1984; 223:4656.

68. Penfield W, McNaughton F. Dural headache and innervations of the dura mater. Arch Neurol Psychiatry 1940; 44:43-75.

69. Moskowitz MA. Neurogenic inflammation in the pathophysiology and treatment of migraine. Neurology 1993; 43(Suppl 3):16-20.

70. Moskowitz MA, Nozaki K, Kraig RP. Neocortical spreading depression provokes the expression of $c$-fos protein-like immunoreactivity within trigeminal nucleus caudalis via trigeminovascular mechanisms. J Neurosci 1993; 13:1167-1177.

71. Olesen J, Iversen HK, Thomsen LL. Nitric oxide supersensitivity: a possible molecular mechanism of migraine pain. Neuroreport 1993; 4:1027-1030.

72. Reuter U, Bolay H, Jansen-Olesen I, Chiarugi A, Sanchez del Rio M, Letourneau R, Theoharides TC, Waeber C, Moskowitz MA. Delayed inflammation in rat meinges: implications for migraine pathophysiology. Brain 2001; 124:2490-2502.

73. McCleskey EW, Gold MS. Ion channels of nociception. Annu Rev Physiol 1999; 61:835-856

74. StrassmanAM, LevyD. Response properties of dural nociceptors in relation to headache. J Neurophysiol 2006; 95:1298-1306.

75. Levy D, Strassman AM. Mechanical response properties of A and C primary afferent neurons innervating the rat intracranial dura. J Neurophysiol 2002 88:3021-3031.

76. Fellin T, Sul JY, D'Ascenzo M, Takano H, Pascual O, Haydon PG. Bidirectional astrocyte-neuron communication: the many roles of glutamate and ATP. Novartis Found Symp 2006; 276:208-217.

77. Haydon PG, Carmignoto G. Astrocyte control of synaptic transmission and neurovascular coupling. Physiol Rev 2006; 86:1009-1031. 
78. Zonta M, Angulo MC, Gobbo S, Rosengarten B, Hossmann KA, Pozzan T, Carmignoto $\mathrm{G}$. Neuron-toastrocyte signaling is central to the dynamic control of brain microcirculation. Nat Neurosci 2003; 6:43-50

79. Mulligan SJ, MacVicar BA. Calcium transients in astrocyte endfeet cause cerebrovascular constrictions. Nature 2004; 431:195-199.

80. Takano T, Tian GF, Peng W, Lou N, Libionka W, Han X, Nedergaard M. Astrocyte-mediated control of cerebral blood flow. Nat Neurosci 2006; 9:260-267.

81. Moskowitz MA. The neurobiology of vascular head pain. Ann Neurol 1984; 15:157-168.

82. Longmore J, Shaw D, Smith D, Hopkins R, McAllister G, Pickard JD, Sirinathsinghji DJ, Butler AJ, Hill RG. Differential distribution of 5-HT 1D and 5-HT 1B immunoreactivity within the human trigemino-cerebrovascular system: implications for the discovery of new anti-migraine drugs. Cephalalgia 1997; 17:835-842.

83. Hoskin KL, Kaube H, Goadsby PJ. Central activation of the trigeminovascular pathway in the cat is inhibited by dihydroergotamine. A c-Fos and electrophysiological study. Brain 1996; 119:249-256.
84. Tajti J, Uddman R, Edvinsson L. Neuropeptide localization in the 'migraine generator' region of the human brainstem. Cephalalgia 2001; 21:96-101.

85. Jenkins DW, Langmead CJ, Parsons AA, Strijbos PJ. Regulation of calcitonin gene-related peptide release from rat trigeminal nucleus caudalis slices in vitro. NeurosciLett 2004; 366:241-244.

86. Offenhauser N, Zinck T, Hoffmann J, Schiemann K, Schuh-Hofer S, Rohde W, Arnold G, Dirnagl U, Jansen-Olesen I, Reuter U. CGRP release and c-fos expression within trigeminal nucleus caudalis of the rat following glyceryltrinitrate infusion. Cephalalgia 2005; 25:225-236.

87. D'Hanis $W$, Linke R, Yilmazer-Hanke DM. Topography of thalamic and parabrachial calcitonin gene-related peptide (CGRP) immunoreactive neurons projecting to subnuclei of the amygdala and extended amygdala. J Comp Neurol 2007; 505:268-291.

88. Goadsby PJ, Edvinsson L. Human in vivo evidence for trigeminovascular activation in cluster headache. Neuropeptide changes and effects of acute attacks therapies. Brain 1994; 117:427-434.

89. Matharu MS, Goadsby PJ. Persistence of attacks of cluster headache after trigeminal nerve root section. Brain 2002; 125:976-984. 